Lambert, M. \& Neish, A. C. (1950). Canad.J. Res. B, $28,83$. LePage, G. A. (1945). In Umbreit, W. W., Burris, R. H. \& Stauffer, J. F., Manometric Techniques and Related Methods for the Study of Tissue Metabolism, p. 181. Minneapolis: Burgess Publishing Co.

LePage, G. A. (1949). Biochem. Prep. 1, 28.

Lwoff, A. (1934). Zbl. Bakt. (1. Abt.), 130, 498.

Lwoff, M. (1940). Recherches sur le pouvoir de synthèse des Flagellés Trypanosomides, p. 26. Paris: Masson.

Lwoff, M. (1951). Biochemistry and Physiology of Protozoa (ed. A. Lwoff), 1, 129. New York: Academic Press.

Nicloux, M., le Breton, E. \& Doutcheff, A. (1934). Bull. Soc. Chim. biol., Paris, 16, 1314.
Noguchi, H. \& Tilden, E. B. (1926). J. exp. Med. 44, 307.

Quastel, J. H. \& Wheatley, A. H. M. (1938). Biochem. J. 32 , 936.

Rapoport, S. (1937). Biochem. Z. 289, 406.

Reiner, L., Smythe, C. V. \& Pedlow, J. T. (1936). J. biol. Chem. 113, 75.

Robbie, W. A. (1946). J. cell. comp. Physiol. 27, 181.

Roe, J. H. (1934). J. biol. Chem. 107, 15.

Ryley, J. F. (1951). Biochem. J. 49, 577.

Ryley, J. F. (1952). Biochem. J. 52, 483.

Ryley, J. F. (1955). Biochem. J. 59, 361.

Somogyi, M. (1945). J. biol. Chem. 160, 61.

Warburg, O. \& Christian, W. (1943). Biochem. Z. 314, 149.

\title{
Studies on the Metabolism of the Protozoa
}

\section{METABOLISM OF THE PARASITIC FLAGELLATE TRICHOMONAS FOETUS*}

\author{
By J. F. RYLEY \\ Imperial Chemical (Pharmaceuticals) Limited, Biological Laboratories, Morley, Wilmslow, Cheshire
}

(Received 12 August 1954)

Trichomonas foetus is a flagellated protozoon parasitic in the reproductive tracts of bovines. It has a venereal transmission, and is one cause of abortion in cattle. It was first obtained in bacteriafree culture by Witte (1933), and since then numerous biochemical observations have been made on the flagellate in culture, but it was not until 1951 that Suzuoki \& Suzuoki (1951) carried out an investigation of the parasite in washed suspension. These workers studied particularly the metabolism of added glucose, and the sensitivity of this metabolism to inhibitors. They failed, however, to recognize the importance of the considerable intracellular glycogen reserves in the energy metabolism of the flagellate, and the relationship of this metabolism to that of extracellular substrates. In the present study, attention has been focused on the glycogen reserves of the parasite as the centre of its catabolic activities, and a number of enzyme systems have been demonstrated in cell-free preparations.

\section{MATERIAL AND METHODS}

Organisms. The Belfast strain of Trichomonas foetus, the McEntegart strain of $T$. vaginalis, and a strain of $T$. gallinae isolated in 1951 by $\mathrm{Dr}$ L. P. Joyner from a croplesion of a pigeon, were kindly supplied by my colleague $\mathrm{Mr}$ W. R. Jones. Stock cultures were maintained in the C.P.L.M. medium of Johnson \& Trussell (1943). For bulk growth, $T$. vaginalis was cultivated in McEntegart's (1952) medium containing $10 \%(v / v)$ horse serum, while $T$. foetus and $T$. gallinae were cultivated in a peptone-lemco medium which

\footnotetext{
* Part 4, Ryley (1955).
}

contained $1 \%(w / v)$ 'Oxoid' brand bacteriological peptone, $0.5 \%(w / v)$ 'Oxoid' Lab-lemco (Oxo Ltd.) and $0.5 \%(w / v)$ $\mathrm{NaCl}$. The $\mathrm{pH}$ was adjusted to $8 \cdot 4$, using phenolphthalein as indicator, and the medium was then boiled for $5 \mathrm{~min}$. to precipitate phosphates. After cooling, the solution was filtered, the $\mathrm{pH}$ adjusted to $7 \cdot 3$, and $0 \cdot 3 \%(\mathrm{w} / \mathrm{v})$ glucose added. The medium was autoclaved, and after cooling, $7 \%$ $(\mathrm{v} / \mathrm{v})$ sterile horse serum was added. Amounts (150 ml.) of this medium were inoculated with a tube of culture in C.P.L.M. medium, and after $48 \mathrm{hr}$. growth at $37^{\circ}$, half the culture was inoculated into a further 1.5 l. of the same medium. After $48 \mathrm{hr}$. growth, the organisms were harvested with a centrifuge, and washed and suspended in Ringerphosphate or Ringer-bicarbonate solutions as described by Ryley (1955).

Materials. The glycogen used in the investigations of intermediary metabolism was a purified specimen prepared from $T$. foetus (Manners \& Ryley, 1955). Adenosine triphosphate (ATP), cozymase and cytochrome $c$ were prepared as described by Ryley (1955), while Ca fructose 1:6diphosphate and $\mathrm{K}$ glucose 1-phosphate were obtained from L. Light and Co. Ltd.

Methods. The methods used were the same as those employed with Strigomonas oncopelti, (Ryley, 1955), except that all experiments were carried out at $37^{\circ}$. Metabolic rates were again based on nitrogen or dry-weight determinations. From a number of experiments, it was found that $1 \mathrm{mg}$. cellular $\mathrm{N}$ was equivalent to $0.95 \times 10^{8}$ flagellates, $10.3 \mathrm{mg}$. dry weight or about $64 \mathrm{mg}$. wet weight; these relationships are only approximate, due to the variable glycogen content of the organism; it should be noted that Suzuoki \& Suzuoki (1951) state that 'the dry weight of $10^{7}$ parasites was about $10 \mathrm{mg}$.', a relationship in error by a factor of ten. The present studies were carried out over the same period of time as those reported in the previous paper for S. oncopelti (Ryley, 1955); this gave a check on the methods employed, which in several cases gave negative results with $T$. foetus. 


\section{RESULTS}

In the following paragraphs, it will be shown that the energy metabolism of Trichomonas foetus centres round its intracellular glycogen reserves, supplemented by any extracellular substrates available. These are degraded under both aerobic and anaerobic conditions to a mixture of succinic and acetic acids, carbon dioxide, and another gas, which has been shown by Suzuoki \& Suzuoki (1951) to be hydrogen. The production of hydrogen rather complicates the manometry, and in the section 'Anaerobic metabolism' the gas exchanges calculated as carbon dioxide represent the sum of carbon dioxide produced by fermentation and due to acid formation, and hydrogen. The techniques available during the course of the present study made the simultaneous measurement of oxygen, hydrogen and carbon dioxide changes impossible, and in the section 'Aerobic metabolism', gas exchanges calculated as oxygen uptake represent the sum of oxygen consumed and hydrogen evolved in a system free from carbon dioxide.

\section{Aerobic metabolism}

Respiratory activity. Under aerobic conditions, $T$. foetus maintains respiration and motility for considerable periods of time at the expense of its intracellular glycogen; from a series of eighteen experiments, an average ' $q_{\mathrm{O}_{2}}$ ' ( $\mu \mathrm{l} . \mathrm{O}_{2}$ consumed/ mg. $\mathrm{N} / \mathrm{hr}$.) of 176 was obtained (range 113-255). Twenty-two substrates were tested at a final concentration of $0.02 \mathrm{M}$ for their ability to stimulate the respiration of the flagellate in a phosphate buffer; these substances can be divided into five groups: (a) Glucose, fructose and mannose stimulated respiration by 75-125\%. (b) Galactose and lactose stimulated respiration by $50-75 \%$. (c) Maltose, sucrose, L-glutamate and glutamine stimulated respiration by $10-25 \%$. (d) DL-Aspartate, asparagine, formate, acetate, propionate, butyrate, lactate, citrate and succinate gave respiratory stimulations of up to $10 \%$. (e) Glycerol, ethanol, pyruvate and DL-alanine were without effect on the rate of respiration.

Effect of inhibitors on respiration and motility. A number of compounds were examined for their ability to inhibit respiration and motility. As indicated in Table 1, most of these substances had little inhibitory effect on endogenous respiration, and in many cases produced a small stimulation; on the other hand, many of them were able to reduce, and in some cases, abolish motility. The most effective inhibitor was iodoacetate, but even with a concentration of $0.01 \mathrm{M}, 20 \%$ of the endogenous respiration was retained over the first hour; the effect of this compound increased with time of incubation. Arsenite, another sulphydryl-inhibitor, produced a small stimulation rather than an inhibition of respiration; motility however was reduced almost to zero. A similar uncoupling of respiration and motility was produced by azide. Thus $0.01 \mathrm{~m}$ azide at $\mathrm{pH} 5.5$ gave a significant stimulation of respiration, while motility was practically abolished; at $\mathrm{pH} 6 \cdot 2$, the same concentration of azide was without effect on respiration, but had an adverse effect on the motility of the flagellates. At $\mathrm{pH} 5.5 \quad 0.001 \mathrm{~m}$ azide produced similar but smaller effects, but was without action at $\mathrm{pH} 6 \cdot 2$. 2:4-Dinitrophenol at $\mathrm{pH} 5 \cdot 5$ inhibited both respiration and motility, although at $\mathrm{pH} 6 \cdot 2$ there was little effect on either process with concentrations as great as $0.003 \mathrm{M}$. While $0.01 \mathrm{~m}$ hydroxylamine inhibited respiration by only $10 \%$, it produced a marked reduction in motility. However, this same concentration of hydroxylamine produced a $44 \%$ inhibition of respiration in the presence of added glucose, motility again being reduced to a low level.

\section{Haem compounds}

Spectroscopic examination of thick suspensions of the flagellate reduced with a little sodium dithionite $\left(\mathrm{Na}_{2} \mathrm{~S}_{2} \mathrm{O}_{4}\right)$, either at room temperature, or after cooling in liquid nitrogen, failed to show any absorption bands. Similarly, examination of a wellaerated suspension of the organism did not reveal any bands due to oxyhaemoglobin.

Spectroscopic evidence suggests that the cytochromes, if present, occur in only minute amounts. Attempts were made to detect cytochrome oxidase, using the oxidation of $p$-phenylenediamine as a

\section{Table 1. Effect of inhibitors on respiration and motility of Trichomonas foetus}

Each manometer cup contained about $1 \mathrm{mg}$. flagellate $\mathrm{N}$ in a total vol. of $1.5 \mathrm{ml}$.; inhibitor added from side bulb, and respiration followed for period of $1 \mathrm{hr}$.; gas phase air; temp. $37^{\circ}$; organisms examined at end of experiment, and motility assessed as 0 (immobile),,+++ or +++ ; negative inhibition indicates respiratory stimulation.

\begin{tabular}{|c|c|c|c|}
\hline Inhibitor & $\begin{array}{c}\text { Concentration } \\
\text { (M) }\end{array}$ & $\begin{array}{c}\text { Inhibition } \\
(\%)\end{array}$ & Motility \\
\hline $\begin{array}{l}\text { Potassium cyanide } \\
\text { Sodium fluoride }\end{array}$ & $\begin{array}{l}0.46 \times 10^{-8} \\
0.04\end{array}$ & $\begin{array}{l}0 \\
8\end{array}$ & $\begin{array}{c}++ \\
+\end{array}$ \\
\hline Sodium arsenite & $\begin{array}{l}0.04 \\
0.01 \\
0.01\end{array}$ & $\begin{array}{r}-21 \\
-15 \\
80\end{array}$ & $\begin{array}{l}\mathbf{0} \\
\mathbf{0} \\
\mathbf{0}\end{array}$ \\
\hline Iodoacetate & $\begin{array}{l}0.001 \\
0.0001\end{array}$ & $\begin{array}{l}61 \\
30\end{array}$ & $\begin{array}{l}0 \\
0\end{array}$ \\
\hline Sodium malonate & 0.04 & -12 & +++ \\
\hline Phenylthiourea & 0.001 & -7 & +++ \\
\hline 2:2'-Ďipyridyl & 0.001 & 1 & ++ \\
\hline 8-Hydroxyquinoline & 0.001 & -20 & ++ \\
\hline Hydroxylamine & 0.01 & 10 & + \\
\hline Azide (pH 5.5) & $\begin{array}{l}0.01 \\
0.001\end{array}$ & $\begin{array}{l}-32 \\
-10\end{array}$ & $\begin{array}{l}0 \\
+\end{array}$ \\
\hline 2:4-Dinitrophenol & 0.001 & 12 & + \\
\hline
\end{tabular}


criterion of activity. Thick homogenates of the trichomonad respired with a $q_{0_{2}}$ of from 6 to 12 ; on the addition of $p$-phenylenediamine, the oxygen uptake was stimulated by from two- to fourfold. This extra oxygen uptake could not all be accounted for by the spontaneous oxidation of the $p$-phenylenediamine. Added cytochrome $c$ did not produce any stimulation of the oxidation.

Both whole cells and homogenates of $T$. foetus decompose hydrogen peroxide. The catalase activity of the organism is gradually destroyed by peroxide; thus when thick homogenates or cell suspensions were incubated with $10 \mu$ moles hydrogen peroxide, the peroxide was completely broken down within five minutes. When, however, thin homogenates or cell suspensions were used, the peroxide breakdown was slower, and oxygen evolution gradually came to a standstill before all the peroxide had been decomposed, indicating that the catalase system had been inactivated; addition of horse-liver catalase to the system liberated the oxygen from the residual peroxide. Although $T$. foetus contains an active catalase, $0.005 \mathrm{~m}$ hydrogen peroxide reduced motility considerably, especially in the case of thin cell suspensions; it is interesting to note that hydrogen peroxide has been used for the treatment of $T$. foetus infection in bulls.

In contrast to the marked catalase activity of $T$. foetus, similar experiments carried out with $T$. vaginalis and $T$. gallinae showed that these flagellates contain no catalase; motility of the organisms is readily abolished by peroxide.

\section{Anaerobic metabolism}

Under anaerobic conditions, motility of $T$. foetus is maintained at the aerobic level by fermentation of the intracellular glycogen reserves. In a bicarbonate medium, gas evolution takes place with a ' $q$ 's, ', of about 325; this gas evolution is almost doubled in the presence of glucose or fructose, galactose or lactose have a smaller effect, while maltose stimulates gas production by about $15 \%$.

Effect of inhibitors. The effect of a number of inhibitors on endogenous anaerobic metabolism was examined. As can be seen from Table 2, the most effective inhibitor was iodoacetate, which gave $88 \%$ inhibition of gas production at a concentration of $0.0003 \mathrm{M}$; lower concentrations were not very effective until the cells had been metabolizing in the presence of inhibitor for some time. In contrast to the effect on aerobic metabolism, arsenite gave a small inhibition rather than a stimulation of anaerobic metabolism. High concentrations of arsenite, fluoride, and azide, although not reducing fermentation greatly, reduced motility to a low level; cells which became sluggish owing to the presence of effective inhibitors, also tended to become round in shape.

\section{Glycogen metabolism}

Glycogen synthesis and utilization by the trichomonads can be followed in washed suspensions. Tables 3 and 4 indicate that washed suspensions of

\section{Table 2. Effect of inhibitors on anaerobic metabolism and motility}

Each manometer cup contained about $1.3 \mathrm{mg}$. flagellate $\mathrm{N}$ in a total vol. of $1.5 \mathrm{ml}$; gas phase $5 \% \mathrm{CO}_{2}-95 \% \mathrm{~N}_{2}$. Inhibitor added from side bulb, and endogenous fermentation followed for period of $1 \mathrm{hr}$. Flagellates examined on slide in air at the end of the experiment, and motility assessed as in Table 1 .

\begin{tabular}{|c|c|c|c|}
\hline Inhibitor & $\begin{array}{c}\text { Concentration } \\
\text { (M) }\end{array}$ & $\begin{array}{c}\text { Inhibition } \\
(\%)\end{array}$ & Motility \\
\hline Potassium cyanide & 0.01 & 25 & $+t+$ \\
\hline Sodium fluoride & $0 \cdot 04$ & 14 & + \\
\hline & 0.02 & 22 & + \\
\hline Sodium arsenite & 0.002 & 22 & +++ \\
\hline & 0.001 & 8 & +++ \\
\hline $\begin{array}{l}\text { Iodoacetate } \\
\text { Phenvlthiourea }\end{array}$ & 0.0003 & 88 & $\begin{array}{c}0 \\
+++\end{array}$ \\
\hline 2:2'-Dipyridyl & 0.001 & $\mathbf{3 0}$ & $\begin{array}{l}+++ \\
+++\end{array}$ \\
\hline 8-Hydroxyquinoline & 0.001 & 10 & +++ \\
\hline Sodium azide & 0.02 & 26 & + \\
\hline
\end{tabular}

\section{Table 3. Glycogen utilization and formation} in washed suspensions (aerobic)

Manometer cups contained $\mathbf{0 . 5 3} \mathrm{mg}$. flagellate $\mathrm{N}$ and $22.5 \mu$ moles substrate in total vol. of $1.5 \mathrm{ml}$.; gas phase $\mathrm{CO}_{\mathrm{a}}$-free air. System incubated for $90 \mathrm{~min}$. and $0.2 \mathrm{ml}$. $2 \mathrm{~N}-\mathrm{H}_{2} \mathrm{SO}_{4}$ added from side bulb. Reducing sugar and glycogen estimated in manometer contents after neutralization. Oxygen uptakes have not been corrected for hydrogen production.

\begin{tabular}{|c|c|c|c|}
\hline Substrate & $\begin{array}{c}\text { Oxygen } \\
\text { used } \\
\text { ( } \mu \text { moles) }\end{array}$ & $\begin{array}{c}\text { Sugar used } \\
\text { ( } \mu \text { moles } \\
\text { hexose } \\
\text { equiv.) }\end{array}$ & $\begin{array}{c}\text { Glycogen } \\
\text { change } \\
\text { (as } \mu \text { mol. } \\
\text { glucose) }\end{array}$ \\
\hline $\begin{array}{l}\text { None } \\
\text { Glucose } \\
\text { Maltose } \\
\text { Galactose } \\
\text { Lactose }\end{array}$ & $\begin{array}{l}\mathbf{5} \cdot 54 \\
\mathbf{9} \cdot \mathbf{8 7} \\
\mathbf{6} \cdot \mathbf{7 0} \\
\mathbf{8 . 5 7} \\
\mathbf{8 . 5 4}\end{array}$ & $\begin{array}{r}0.00 \\
11 \cdot 93 \\
3 \cdot 00 \\
9 \cdot 21 \\
9 \cdot 64\end{array}$ & $\begin{array}{l}-\mathbf{3} .26 \\
+\mathbf{4} .79 \\
-\mathbf{1} .34 \\
+\mathbf{3} .51 \\
+\mathbf{3} .22\end{array}$ \\
\hline
\end{tabular}

Table 4. Glycogen utilization and formation in washed suspension (anaerobic)

Cell suspension $(0 \cdot 21 \mathrm{mg}$. $N)$ incubated in Ringerbicarbonate medium with $22.5 \mu$ moles substrate for period of 80 min.; gas phase $5 \% \mathrm{CO}_{2}-95 \% \mathrm{~N}_{2}$. Reaction stopped by adding acid from side bulb, and reducing sugar and glycogen estimated in manometer contents after neutralization.

\begin{tabular}{|c|c|c|c|}
\hline Substrate & $\begin{array}{c}\text { Acid } \\
\text { formed } \\
\text { ( } \mu \text { equiv.) }\end{array}$ & $\begin{array}{c}\text { Sugar used } \\
\text { ( } \mu \text { moles } \\
\text { hexose } \\
\text { equiv.) }\end{array}$ & $\begin{array}{c}\text { Glycogen } \\
\text { change } \\
\text { (as } \mu \text { moles } \\
\text { glucose) }\end{array}$ \\
\hline $\begin{array}{l}\text { None } \\
\text { Glucose } \\
\text { Fructose } \\
\text { Maltose } \\
\text { Galactose } \\
\text { Lactose }\end{array}$ & $\begin{array}{r}7 \cdot 78 \\
15 \cdot 74 \\
15 \cdot 52 \\
9 \cdot 06 \\
13 \cdot 03 \\
13 \cdot 48\end{array}$ & $\begin{array}{l}0 \cdot 00 \\
6 \cdot 83 \\
6 \cdot 30 \\
0 \cdot 91 \\
4.05 \\
5 \cdot 32\end{array}$ & $\begin{array}{l}-2.40 \\
+3.78 \\
+2.55 \\
-1.31 \\
+0.56 \\
+0.08\end{array}$ \\
\hline
\end{tabular}


the flagellate utilize intracellular glycogen under both aerobic and anaerobic conditions. Maltose exerts a slight sparing effect on the glycogen utilization, while in the presence of glucose, fructose, galactose or lactose, although there is an increase in metabolic rate - oxygen uptake or acid formationthere is a net synthesis rather than breakdown of intracellular glycogen.

During the course of its metabolism, $T$. foetus has been shown to produce hydrogen. Hydrogen production can be measured along with carbon dioxide and acid changes under anaerobic conditions using the Dickens \& Šmer technique; hydrogen production in a carbon dioxide-free system can also be followed under anaerobic conditions in ordinary Warburg manometers. Table 5 illustrates an experiment in which glycogen fermentation, and the production of hydrogen, carbon dioxide, succinic and acetic acids was followed under anaerobic conditions. It can be seen that there was a greater utilization of glycogen in the presence of carbon dioxide, and that when present, a small amount of carbon dioxide was assimilated. In the absence of carbon dioxide in the gas phase, the yields of succinic acid per mole hexose utilized were lower, while those of hydrogen, carbon dioxide and acetic acid were correspondingly higher. It should be noted that in view of these results, the direct method of Warburg-using two manometers, one with potassium hydroxide in the centre well, to determine hydrogen and carbon dioxide production under a nitrogen gas phase-is not justifiable, and the figure for carbon dioxide formed in the centre line of Table 5 is only an approximation.

Analysis of the suspending medium after a period of aerobic or anaerobic metabolism showed that the main products of glycogen breakdown were acetic and succinic acids; from Table 6 it can be seen that aerobic conditions favoured the production of acetic acid at the expense of succinic acid, while glycogen breakdown was approximately twice as great under anaerobic as under aerobic conditions. The acetic acid was measured by titration after steam distillation in the presence of mercuric oxide; control experiments showed that this procedure destroyed formic acid. Distillation in the absence of

\section{Table 5. Effect of environment on anaerobic metabolism}

Manometer cups contained 1.24 mg. flagellate $\mathrm{N}$ in total vol. of $2.0 \mathrm{ml}$; ; one series utilized Ringer-bicarbonate medium and Dickens \& Simer manometer flasks with a gas phase of $5 \% \mathrm{CO}_{2}-95 \% \mathrm{~N}_{2}$, while other series utilized Ringer-phosphate with Warburg flasks, and a gas phase of pure $\mathrm{N}_{2}$ with or without $\mathrm{KOH}$ in the centre well. Reaction stopped after 210 min. incubation by tipping $0.3 \mathrm{ml} .2 \mathrm{~N}_{-} \mathrm{H}_{2} \mathrm{SO}_{4}$ from side bulb; contents of duplicate manometers pooled, and estimations of glycogen, succinic and acetic acids carried out. In series with $\mathrm{CO}_{8}-\mathrm{N}_{2}$ gas phase, total acid produced (bicarbonate destroyed) $36 \cdot 0 \mu$ equiv.

$\begin{array}{lccccc}\text { Gas phase } & \begin{array}{c}\text { Glycogen } \\ (\mu \text { moles } \\ \text { glucose equiv. })\end{array} & \begin{array}{c}\mathrm{H}_{2} \\ (\mu \mathrm{moles})\end{array} & \begin{array}{c}\mathrm{CO}_{2} \\ (\mu \mathrm{moles})\end{array} & \begin{array}{c}\text { Succinic acid } \\ (\mu \mathrm{moles})\end{array} & \begin{array}{c}\text { Acetic acid } \\ (\mu \mathrm{moles})\end{array} \\ \mathrm{CO}_{2}-\mathrm{N}_{2} & -12 \cdot 37 & +7 \cdot 24 & -0.56 & +12.05 & +11 \cdot 11 \\ \mathrm{~N}_{2} & -8.45 & - & +6.59 * & +6.98 & +12.47 \\ \mathrm{~N}_{2}(\mathrm{KOH}) & -7.48 & +8.02 & - & +3.43 & +11.98\end{array}$

* This figure is calculated from the total pressure change in the manometer, assuming that 8.02 $\mu$ moles $\mathrm{H}_{2}$ had been produced.

\section{Table 6. Metabolic products formed during aerobic and anaerobic glycogen breakdown}

Flagellate $\mathrm{N}(8.20 \mathrm{mg}$.) in total vol. of $6.0 \mathrm{ml}$. Ringer-bicarbonate distributed in 3 Dickens \& Simer or 4 Warburg manometer flasks; gas phase air or $\mathrm{N}_{2}$, both containing $5 \% \mathrm{CO}_{2}$. Fermentation stopped after 57 min. by acid, flask contents pooled, neutralized, and samples taken for estimation of various metabolites. Aerobically, total of $10 \cdot 80 \mu \mathrm{moles}$ glycogen (as glucose equiv.) used with the formation of $27 \cdot 40 \mu$ equiv. acid; anaerobically $22 \cdot 25 \mu$ moles glycogen and $4.02 \mu$ moles of $\mathrm{CO}_{2}$ used with the production of $55 \cdot 6 \mu$ equiv. acid and 13.30 $\mu$ moles $\mathrm{H}_{2}$. Yields expressed in terms of moles metabolite found/mole glycogen (as glucose) disappearing, from which values for carbon and acid recoveries have been calculated. Redox values have been calculated by the method of Johnson, Peterson \& Fred (1931); the substrate glycogen has a redox value of 0 .

\begin{tabular}{|c|c|c|c|c|c|c|c|c|}
\hline \multirow[b]{3}{*}{ Metabolite } & \multicolumn{3}{|c|}{ Aerobically } & \multicolumn{5}{|c|}{ Anaerobically } \\
\hline & \multirow[b]{2}{*}{ Moles } & \multirow{2}{*}{$\begin{array}{l}\text { C atoms } \\
\text { (g. atoms) }\end{array}$} & \multirow{2}{*}{$\begin{array}{c}\text { Acid } \\
\text { equiv. } \\
\text { (g. equiv.) }\end{array}$} & \multirow[b]{2}{*}{ Moles } & \multirow{2}{*}{$\begin{array}{c}\mathrm{C} \text { atoms } \\
\text { (g. atoms) }\end{array}$} & \multirow{2}{*}{$\begin{array}{c}\text { Acid } \\
\text { equiv. } \\
\text { (g. equiv.) }\end{array}$} & \multicolumn{2}{|c|}{ Redox values } \\
\hline & & & & & & & $(-)$ & $(+)$ \\
\hline Carbon dioxide & $? ?$ & - & - & $-0 \cdot 18$ & - & - & - & $0 \cdot 36$ \\
\hline Hydrogen & - & - & - & $0 \cdot 60$ & - & -_ & -_ & $0 \cdot 60$ \\
\hline Acetic acid & $1 \cdot 70$ & $3 \cdot 40$ & $1 \cdot 70$ & 0.71 & $1 \cdot 42$ & 0.71 & 0 & 0 \\
\hline Succinic acid & $0 \cdot 44$ & $1 \cdot 76$ & $0 \cdot 88$ & 0.95 & $3 \cdot 80$ & 1.90 & 0.95 & - \\
\hline Sum & - & $5 \cdot 16$ & $\mathbf{2 \cdot 5 8}$ & - & $5 \cdot 22$ & $\mathbf{2} \cdot \mathbf{6 1}$ & 0.95 & 0.96 \\
\hline Acid yield (from bicarbonate used) & - & - & $2 \cdot 53$ & - & - & $2 \cdot 50$ & - & - \\
\hline C atoms supplied & - & $6 \cdot ? ?$ & - & - & $6 \cdot 18$ & - & - & - \\
\hline
\end{tabular}


mercuric oxide did not give any greater yield of volatile acid, indicating that no formic acid was produced during glycogen metabolism. Similarly, application of the colorimetric method of Grant (1947) to a $\mathrm{Ba}(\mathrm{OH})_{2}-\mathrm{ZnSO}_{4}$ filtrate of the metabolic solution failed to detect any formic acid production. Analysis of similar metabolic solutions showed that no detectable amounts of ethanol, glycerol or pyruvic acid were produced, while lactic acid recoveries indicated that not more than 0.05 mole of the acid was produced/mole hexose utilized.

\section{Intermediary carbohydrate metabolism}

Using cell-free preparations (homogenates) made in the Mickle disintegrator, a number of phosphorylative enzyme systems were demonstrated in the flagellate. As with Strigomonas oncopelti, the sensitivity of a number of these systems to 2:2'-dipyridyl was tested. On centrifuging a homogenate prepared by disintegration of an aqueous cell suspension, a yellowish brown, opalescent supernatant was obtained, along with a very small deposit, which on microscopical examination was found to consist of cell walls, looking like empty shells, along with the axostyles of the trichomonads.

Amylase and maltase. Cell-free preparations of Trichomonas foetus, when incubated with starch, glycogen or maltose in the absence of inorganic phosphate, were found to liberate reducing sugar; this is illustrated in Fig. 1. As the only preparation of glucose oxidase available was contaminated with

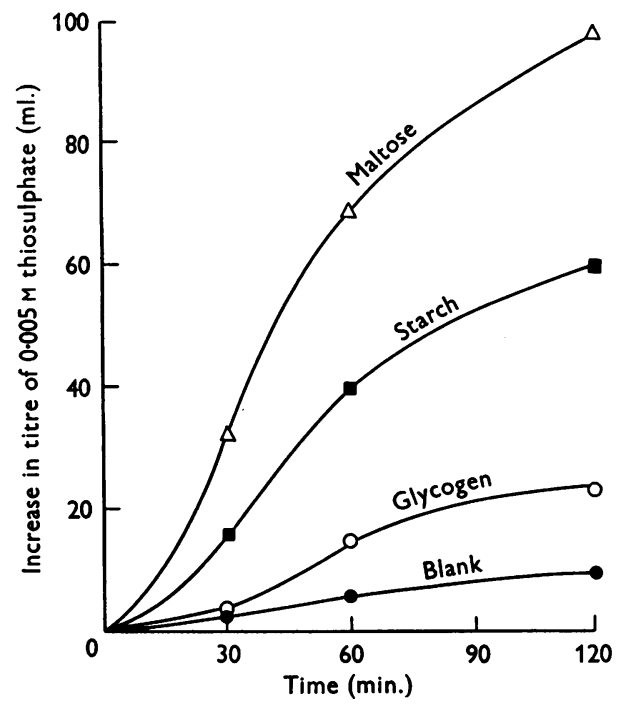

Fig. 1. Carbohydrase activity in $T$. foetus homogenate. Tubes set up to contain $\mathbf{3 6} \mathrm{mg}$. glycogen or starch or $68 \mathrm{mg}$. maltose in $4 \mathrm{ml} .0 .036 \mathrm{M}$ acetate-veronal buffer (pH 7.3); $5 \mathrm{ml}$. homogenate (10 mg. N) added, and samples removed at intervals for estimation of reducing sugar in $\mathrm{Ba}(\mathrm{OH})_{2}-\mathrm{ZnSO}_{4}$ filtrates. maltase, it was not possible to demonstrate glucose as the end product of starch and glycogen hydrolysis. In view of the hydrolytic activity towards maltose, however, it seems probable that glucose was produced from starch and glycogen.

Phosphorylase. Cell-free preparations of $T$. foetus were found to degrade starch or glycogen in the presence of inorganic phosphate. From Fig. 2 it can be seen that starch was attacked more rapidly than glycogen (observed on several occasions), and that some of the phosphate esterified was recovered in combination with fructose. In this particular experiment, there was a liberation of inorganic phosphate on prolonged incubation.

Hexokinase. Besides utilizing intracellular glycogen in its energy metabolism, $T$. foetus is able to metabolize free hexoses. Homogenates of the flagellate were found to phosphorylate glucose in the presence of ATP; and most of the acid-labile phosphate of the ATP was recovered as esterified phosphate, but a small amount was liberated as inorganic phosphate, especially in the absence of glucose (Table 7).

Phosphoglucomutase and ketoisomerase. Although in the phosphorylase and hexokinase systems, the production of fructose compounds has been demonstrated, the ability of the trichomonad to transform glucose 1-phosphate to less easily hydrolysable phosphate compounds and phospho-

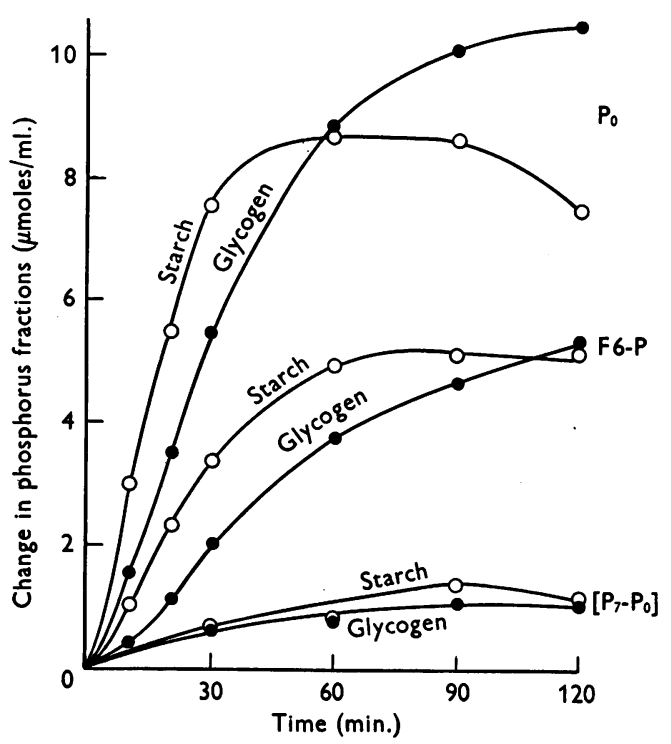

Fig. 2. Phosphorylase activity in $T$. foetus homogenate. Tubes set up to contain $80 \mathrm{mg}$. starch or glycogen in $2.5 \mathrm{ml}$. $0.1 \mathrm{M}$ phosphate buffer (pH 7.3). $7 \cdot 5 \mathrm{ml}$. homogenate (26.1 mg. $\mathrm{N}$ ) added and $1 \mathrm{ml}$. samples removed into $7 \mathrm{ml} .5 \%$ TCA after various intervals of incubation at $37^{\circ}$. Fructose, $P_{0}$ and $P_{7}$ determinations carried out in TCA filtrates. 


\section{Table 7. Hexokinase activity in T. foetus homogenate}

Each manometer cup contained $3.5 \mathrm{mg}$. homogenate $\mathrm{N}$, $0.06 \mathrm{M}-\mathrm{NaF}, 0.006 \mathrm{M}-\mathrm{MgSO}_{4}$ and $0.025 \mathrm{M}-\mathrm{NaHCO}_{3}$ in vol. of $2.4 \mathrm{ml}$; gas phase $5 \% \mathrm{CO}_{2}-95 \% \mathrm{~N}_{2}$. ATP (10.75 $\mu$ moles) and glucose (11.1 $\mu$ moles) added at beginning of experiment, and reaction stopped at end by $0.3 \mathrm{ml}$. $2 \mathrm{~N}-\mathrm{H}_{2} \mathrm{SO}_{4}$. Manometer contents neutralized, and glucose estimated in $\mathrm{Ba}(\mathrm{OH})_{2}-\mathrm{ZnSO}_{4}$ filtrates, and fructose and acid-labile phosphate in TCA filtrates; results expressed in $\mu$ moles.

\begin{tabular}{|c|c|c|}
\hline & Glucose & No glucose \\
\hline Glucose used & $5 \cdot 60$ & - \\
\hline $\mathrm{CO}_{2}$ evolved & $6 \cdot 20$ & $1 \cdot 79$ \\
\hline ATP used $\left[\mathrm{P}_{7}-\mathrm{P}_{0}\right]$ & $6 \cdot 08$ & $2 \cdot 55$ \\
\hline Ester $\mathbf{P}$ formed & $5 \cdot 72$ & $0 \cdot 78$ \\
\hline$P_{0}$ liberated & $0 \cdot 36$ & $1 \cdot 77$ \\
\hline F 6-P formed & 1.97 & - \\
\hline
\end{tabular}

\section{Table 8. Phosphoglucomutase and ketoisomerase activity in $\mathbf{T}$. foetus homogenates}

Each tube contained $\mathbf{0 . 7 5} \mathrm{mg}$. homogenate N, 0.002 M$\mathrm{MgCl}_{2}, 0.02 \mathrm{M}$ acetate-veronal buffer $(\mathrm{pH} 7.5)$ and $3 \mathrm{mg} . \mathrm{K}$ glucose 1-phosphate (G 1-P) in total vol. of $4.5 \mathrm{ml}$; t tubes deproteinized with $1.5 \mathrm{ml} .10 \%$ TCA after 15 or 60 min. incubation at $37^{\circ}$. Figures represent changes in various phosphate fractions expressed in $\mu$ moles. Fructose 6 phosphate (F 6-P) from fructose content of TCA filtrate.

\begin{tabular}{|c|c|c|c|c|}
\hline $\begin{array}{l}\text { Time } \\
\text { (min.) }\end{array}$ & $P_{0}$ & $\begin{array}{l}{\left[\mathrm{P}_{7}-\mathrm{P}_{0}\right]} \\
(\mathrm{G} 1-\mathrm{P})\end{array}$ & {$\left[\mathrm{P}_{t}-\mathrm{P}_{7}\right]$} & F 6-P \\
\hline $\begin{array}{l}15 \\
60\end{array}$ & $\begin{array}{l}+0.19 \\
+0.93\end{array}$ & $\begin{array}{l}-5 \cdot 04 \\
-6 \cdot 02\end{array}$ & $\begin{array}{l}+4.85 \\
+5.09\end{array}$ & $\begin{array}{l}+1.91 \\
+1.94\end{array}$ \\
\hline
\end{tabular}

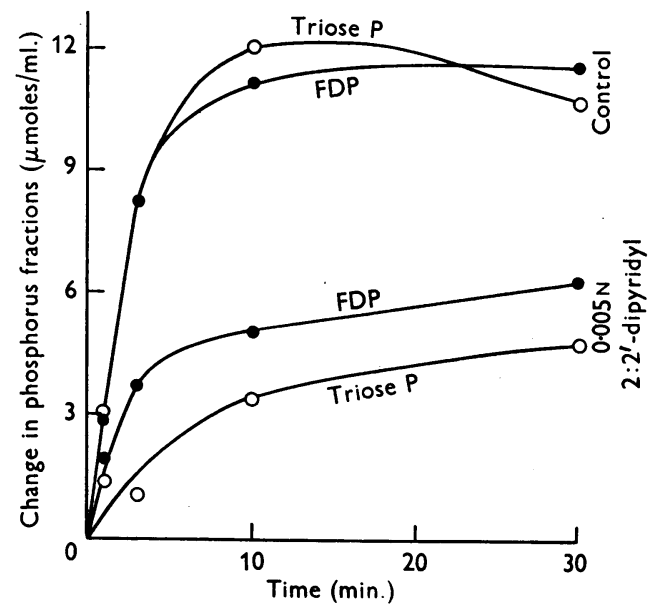

Fig. 3. Aldolase activity in $T$. foetus homogenate. Tubes contained $7.5 \mathrm{mg}$. homogenate $\mathrm{N}, 0.01 \mathrm{M}$ acetate-veronal buffer, $\mathrm{pH} 6 \cdot 0,0.06 \mathrm{M}-\mathrm{NaF}, 0.004 \mathrm{M}$ fructose 1:6-diphosphate (FDP) and 0.005 $\mathrm{m} 2: 2^{\prime}$-dipyridyl where indicated in total vol. of $10 \mathrm{ml}$. Samples $(2 \mathrm{ml}$.) removed into $2 \mathrm{ml}$. $\mathbf{7 . 5} \%$ TCA after incubation at $37^{\circ}$ for various intervals, and fructose and alkali-labile phosphate estimations carried out in filtrates. fructose has been shown directly by incubating homogenates with Cori ester; this is recorded in Table 8.

Fructose diphosphate metabolism. Aldolase activity was demonstrated in homogenates of $T$. foetus by incubating them with fructose diphosphate (FDP) and following the liberation of alkali-labile phosphate. This is illustrated by Fig. 3, which shows that approximately 1 mole only of triose phosphate accumulated for each mole of FDP disappearing; this is doubtless due to further degradation of triose phosphate. In the presence of the ketofixative cyanide, although the initial rate of the reaction was the same, more FDP was eventually converted into triose phosphate. 2:2'-Dipyridyl $(0.005 \mathrm{M})$, either in the presence or in the absence of cyanide, considerably reduced the rate of the aldolase reaction; inhibitions of from 50 to $75 \%$ of the initial reaction rate were observed in a number of experiments.

Attempts were made to show the oxidation of triose phosphate coupled to the reduction of pyruvate, the reaction being followed by the pro-

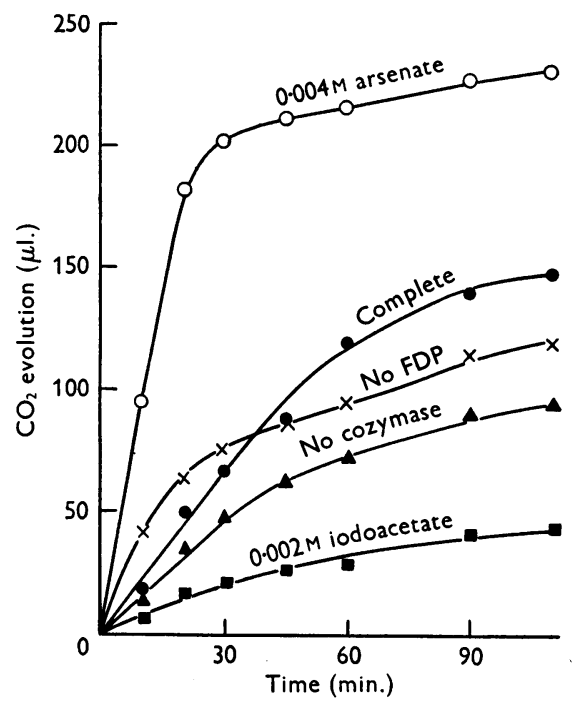

Fig. 4. Fructose diphosphate metabolism by $T$. foetus homogenate. Curves represent $\mathrm{CO}_{2}$ evolution from $0.025 \mathrm{M}-\mathrm{NaHCO}_{8}$ containing $0.008 \mathrm{M}$ FDP, $0.06 \mathrm{M}-\mathrm{NaF}$, $1 \mathrm{mg}$. impure cozymase, $0.005 \mathrm{M}$ pyruvate and $3.7 \mathrm{mg}$. homogenate $\mathrm{N}$ in total vol. of $2.5 \mathrm{ml}$; gas phase $5 \%$ $\mathrm{CO}_{2}-95 \% \mathrm{~N}_{2} ; 0.004 \mathrm{M}$ sodium arsenate or $0.002 \mathrm{M}$ iodoacetate present as indicated. Fructose and alkalilabile phosphate assayed in TCA filtrates at end:

$\begin{array}{lccc}\text { System } & \begin{array}{c}\text { FDP } \\ \text { used } \\ (\mu \text { moles })\end{array} & \begin{array}{c}\text { Triose P } \\ \text { found } \\ (\mu \text { moles })\end{array} & \begin{array}{c}\text { FDP } \\ \text { fermented } \\ (\mu \text { moles })\end{array} \\ \text { Complete } & 7 \cdot 77 & 3 \cdot 92 & 5 \cdot 81 \\ \text { No cozymase } & 4 \cdot 73 & 5 \cdot 82 & 1 \cdot 82 \\ \text { Arsenate } & 14 \cdot 10 & 2 \cdot 09 & 13 \cdot 06 \\ \text { Iodoacetate } & 7 \cdot 85 & \mathbf{7 \cdot 7 2} & \mathbf{3 . 9 9}\end{array}$


duction of acid. Fig. 4 indicates that the homogenate used showed a considerable endogenous acid production. In the presence of FDP, this acid production was somewhat increased, and FDP was utilized, the greater part being metabolized beyond the triose phosphate stage. This fermentation was not affected by the omission of pyruvate from the system, was much reduced by the omission of cozymase, or by the presence of $0.002 \mathrm{M}$ iodoacetate, and was considerably stimulated by the presence of $0.004 \mathrm{M}$ arsenate; $0.005 \mathrm{M} 2: 2^{\prime}$-dipyridyl was without effect on the rate of fermentation of FDP.

Dehydrogenases. Attempts were made to detect dehydrogenase activity both by the Thunberg tube technique and manometrically using ferricyanide as hydrogen acceptor. In both cases, however, dehydrogenase activity was marked without the addition of substrates, although lactate very slightly accelerated methylene-blue reduction. Succinate and lactate were on occasions able to increase the oxygen uptake of homogenates, but here again the results were not consistent, owing no doubt to the presence of substrates in the homogenate which were responsible for the appreciable endogenous respiration.

\section{DISCUSSION}

During growth, Trichomonas foetus synthesizes large amounts of intracellular glycogen. This glycogen is partially derived from the nitrogenous components of the medium, but there is a greater synthesis in the presence of added carbohydrate (Manners \& Ryley, 1955). When transferred to a non-nutrient medium, the flagellate utilizes these glycogen reserves with the production of organic acid and hydrogen. The transformation of extracellular simple carbohydrate to intracellular polysaccharide can be demonstrated in washed suspensions of the flagellate; on the addition of glucose, fructose, galactose or lactose, there is an increased production of organic acid, but at the same time a net synthesis of intracellular carbohydrate takes place. In their study of the metabolism of added glucose, Suzuoki \& Suzuoki (1951) failed to recognize this simultaneous assimilation, and so their figures for acid yield and oxygen utilization, when expressed in terms of glucose disappearing, are erroneous. They found that glucose fermentation resulted in the production of large amounts of succinic acid, and that only insignificant amounts of lactic and pyruvic acids accumulated. The residue of the organic acid formed during glycogen fermentation has been accounted for as acetic acid; no evidence could be found for the production of formic acid, nor for its utilization by whole cells or homogenates. It seems likely that $T$. foetus contains a phosphoroclastic system similar to that of Clostridium butyricum (see Wolfe \& O'Kane, 1953), and that pyruvate is broken down to 'active' acetate, hydrogen and carbon dioxide, without the intermediate production of formate, as is the case with Escherichia coli. It is of interest to note that Kupferberg, Singher, Lampson, Levy \&. Romano (1953) find that lactic acid accounts for most of the acid produced during growth of Tri. chomonas vaginalis.

There seems to be some variation between different strains in their ability to metabolize various carbohydrates; thus it is generally contended that $T$. foetus utilizes maltose, Suzuoki \& Suzuoki finding that this sugar stimulated respiration by $136 \%$, while Cailleau (1937) found it was fermented during growth. Our strain, however, is only slightly stimulated by maltose, and this sugar is unable to completely replace endogenous glycogen to support normal metabolism, as is the case with glucose, fructose, mannose, galactose or lactose. Our strain also differs from that of Suzuoki \& Suzuoki in that it readily utilizes lactose, but neither sucrose nor glycerol.

Riedmiiller (1936) found that the respiration of $T$. foetus was insensitive to $95 \%$ carbon monoxide in the gas phase, and he was unable to detect any cytochrome pigments, catalase or peroxidase. Likewise Suzuoki \& Suzuoki found that respiration was insensitive to cyanide, but Professor $K$. Okunuki observed absorption bands at 565 and $535 \mathrm{~m} \mu$. due to cytochrome $b$ in their preparations. In the present study, respiration was found to be insensitive to $0.46 \times 10^{-3} \mathrm{M}$ cyanide, and spectroscopic examination of thick cell suspensions, even with the use of the liquid air technique, failed to reveal absorption bands. Similar procedures had revealed a well-developed cytochrome system in Strigomonas oncopelti, and although it cannot be said that $T$. foetus is devoid of cytochromes, such pigments if present, occur in extremely low concentration, and it would seem that the bulk of cellular respiration is mediated by alternative systems. Cell-free preparations of Trichomonas foetus prepared in the Mickle disintegrator did not show any convincing oxidative activity towards $p$-phenylenediamine, suggesting the absence of cytochrome oxidase. Seaman (1954), in reference to similar results previously obtained with Tetrahymena pyriformis (Ryley, 1952), has contended that this lack of activity is due to the method of preparing the homogenates, which in his opinion destroys most of the enzyme systems originally present in the cells; Eichel (1954) also disagrees with Seaman concerning the presence of cytochrome oxidase in $T$. pyriformis. It is noteworthy that cytochrome oxidase activity can be readily detected by the present technique in Trypanosoma lewisi and Strigomonas oncopelti (Ryley, 1951, 1955), 
and that although Trichomonas foetus homogenates do not show cytochrome oxjdase activity, such preparations are far from being metabolically inactive.

Among the enzyme systems which have been demonstrated in homogenates of the trichomonad, the aldolase system is of particular interest. 2:2' Dipyridyl, in a concentration of $0.005 \mathrm{M}$ inhibited triose phosphate formation by up to $75 \%$, suggesting that the enzyme system involved requires ferrous iron for activity (see Ryley, 1953). Baernstein (1954) has recently reported that the aldolase system of $\boldsymbol{T}$. vaginalis is sensitive to dipyridyl; he obtained $75 \%$ inhibition of activity with $0.01 \mathrm{M}$ 2:2'-dipyridyl, and found that the inhibition was completely reversed by $10^{-3} \mathrm{M}$ ferrous or $10^{-5} \mathrm{M}$ cobaltous salts. In the case of $T$. foetus, the aldolase system is not rate-limiting in carbohydrate breakdown, even in the presence of dipyridyl, as this inhibitor has little effect on the respiration or fermentation of whole cells, or acid formation from hexose diphosphate by homogenates.

Suzuoki \& Suzuoki (1951) state that 'the carbohydrate metabolism of $T$. foetus seems to bear rather striking similarities to that of the African pathogenic trypanosomes', a fact which they suggest should help in the search for potential antitrichomonad drugs. While it cannot be denied that the respiration of both the pathogenic trypanosomes and trichomonads is independent of cytochrome pigments, it should be noted that with the pathogenic trypanosomes, cyanide usually produces an appreciable respiratory stimulation (von Brand \& Johnson, 1947). Perhaps the most striking feature in the carbohydrate metabolism of the pathogenic trypanosomes, when compared with more primitive members of the family, is the tendency to lose the ability to degrade carbohydrate beyond the pyruvate stage, equimolecular amounts of glycerol and pyruvic acid being produced under anaerobic conditions and pyruvic acid being the main metabolic product under aerobic conditions. $T$.foetus, on the other hand, carries its carbohydrate metabolism beyond the pyruvate stage, giving rise to succinic and acetic acids; such is the case with the more primitive trypanosomes, e.g. T. lewisi. Hydrogen and possibly methane, which are also produced during carbohydrate breakdown by $T$. foetus, are unusual metabolites for protozoa.

\section{SUMMARY}

1. The parasitic flagellate Trichomonas foetus can maintain metabolism and motility in the absence of extracellular nutrients for considerable periods at $37^{\circ}$ under both aerobic and anaerobic conditions; this endogenous metabolism depends on the fermentation of intracellular glycogen.

2. Under aerobic conditions, the parasite respires with a $q_{\mathrm{O}_{2}}$ of about 176 at $37^{\circ}$. This oxygen uptake is doubled in the presence of either glucose, fructose or mannose, and is considerably stimulated by both galactose and lactose, while maltose, sucrose, glutamate and glutamine give small respiratory stimulations.

3. Respiration of the flagellate is probably independent of cytochrome pigments; no evidence for the presence of cytochromes could be obtained by spectroscopic examination, by the use of respiratory inhibitors, or by the use of cell homogenates with $p$-phenylenediamine. T. foetus shows vigorous catalatic activity; $T$.vaginalis and $T$.gallinae do not contain catalase.

4. At $\mathrm{pH} \mathrm{5.5} 0.04 \mathrm{M}$ arsenite or $0.01 \mathrm{~m}$ azide appreciably stimulate the endogenous respiration of $T$. foetus, but at the same time abolish cellular motility.

5. Under anaerobic conditions, endogenous metabolism takes place with a $q_{\text {of }}^{\mathrm{N}}$, of 325 ; this fermentation is $88 \%$ inhibited by $0.0003 \mathrm{M}$ iodoacetate, but is relatively insensitive to other inhibitors tested.

6. Intracellular glycogen disappears on incubation under aerobic or anaerobic conditions in the absence of extracellular substrate; in the presence of glucose, fructose, lactose or galactose, although oxygen uptake or carbon dioxide output is considerably increased, there is a net synthesis of glycogen; maltose exerts a slight sparing action on the utilization of intracellular glycogen.

7. Under aerobic or anaerobic conditions, glycogen is fermented to a mixture of succinic and acetic acids; there is a net formation or assimilation of carbon dioxide depending on the conditions, and a gas other than carbon dioxide is produced. Glycogen breakdown and succinic acid production are favoured by anaerobic conditions and the presence of carbon dioxide in the gas phase.

8. Cell-free preparations contain amylase, maltase, phosphorylase, hexokinase, phosphoglucomutase and ketoisomerase, aldolase and a triose phosphate oxidizing system. The activity of aldolase can be inhibited by as much as $75 \%$ in the presence of 0.005 м 2:2' -dipyridyl.

It is a pleasure to acknowledge the invaluable technical assistance of Miss Margaret Mitchell.

\section{REFERENCES}

Baernstein, H. D. (1954). Fed. Proc. 13, 177.

Brand, T. von \& Johnson, E. M. (1947). J. cell. comp. Physiol. 29, 33.

Cailleau, R. (1937). Ann. Inst. Pasteur, 59, 137.

Eichel, H. J. (1954). J. biol. Chem. 206, 159.

Grant, W. M. (1947). Analyt. Chem. 19, 206.

Johnson, G. \& Trussell, R. E. (1943). Proc. Soc. exp. Biol., N.Y., 54, 245. 
Johnson, M. J., Peterson, W. H. \& Fred, E. B. (1931). J. biol. Chem. 91, 569.

Kupferberg, A. B., Singher, H. O., Lampson, G., Levy, L. \& Romano, A. H. (1953). Ann. N.Y. Acad. Sci. 56, 1006.

Manners, D. J. \& Ryley, J. F. (1955). Biochem. J. 59, 369. McEntegart, M. G. (1952). J. clin. Path. 5, 275.

Riedmüller, L. (1936). Z Zbl. Bakt. (1. Abt.), 137, 428.

Ryley, J. F. (1951). Biochem. J. 49, 577.
Ryley, J. F. (1952). Biochem. J. 52, 483.

Ryley, J. F. (1953). Nature, Lond., 171, 747.

Ryley, J. F. (1955). Biochem. J. 59, 353.

Seaman, G. R. (1954). Arch. Biochem. Biophys. 48, 424.

Suzuoki, Z. \& Suzuoki, T. (1951). J. Biochem., Tokyo, 38, 237.

Witte, J. (1933). Zbl. Bakt. (1. Abt.), 128, 189.

Wolfe, R. S. \& O'Kane, D. J. (1953). J. biol. Chem. 205, 755.

\title{
Studies on the Metabolism of the Protozoa
}

\section{THE GLYCOGENS OF THE PARASITIC FLAGELLATES TRICHOMONAS FOETUS AND TRICHOMONAS GALLINAE*}

\author{
By D. J. MANNERS AND J. F. RYLEY \\ Chemistry Department, University of Edinburgh and Imperial Chemical (Pharmaceuticals) Limited, \\ Biological Laboratories, Morley, Wilmslow, Cheshire
}

(Received 12 August 1954)

The molecular structures of the intracellular carbohydrates synthesized by a number of Protozoa have been the subject of several recent investigations. Bourne, Stacey \& Wilkinson (1950) have examined the polysaccharide synthesized by the flagellate Polytomella coeca; it was found to resemble starch, and could be fractionated into linear and branched components (amylose and amylopectin). The polysaccharides produced by the ciliate Cycloposthium and by a holotrich ciliate present in the rumen of the sheep differ in that they are homogeneous, and have branched structures similar to that of an amylopectin (Forsyth, Hirst \& Oxford, 1953; Forsyth \& Hirst, 1953). In contrast, the ciliate Tetrahymena pyriformis synthesizes a homogeneous polysaccharide which has the properties of a typical animal glycogen (Manners \& Ryley, 1952). During a study of the immunologically specific substances of Trichomonas foetus, Feinberg \& Morgan (1953) isolated a glycogen-like polysaccharide from dried cells in a yield of 5-10\%. The present paper is concerned with the intracellular polysaccharides synthesized by Trichomonas foetus and $T$. gallinae (hereafter designated TFP and TGP respectively) which have been purified and subjected to a detailed structural analysis. The available data indicates that they are branched $\alpha$-1:4-glucosans which resemble glycogen rather than amylopectin in branching characteristics.

\section{MATERIALS AND METHODS}

\section{Materials}

Flagellate preparations. Trichomonas gallinae and the Belfast strain of $T$. foetus were cultivated in a peptonelemco medium containing $2 \%(\mathrm{w} / \mathrm{v})$ glucose as described

$$
\text { * Part 5, Ryley (1955). }
$$

by Ryley (1955). Cells of $T$. gallinae were harvested after $24 \mathrm{hr}$. and those of $T$. foetus after $48 \mathrm{hr}$. incubation at $37^{\circ}$ on the centrifuge, and were washed in $0.9 \%(w / v)$ $\mathrm{NaCl}$.

Maltulose. Maltulose was prepared from maltose as described by Peat, Roberts \& Whelan (1952).

\section{Methods}

Before analysis, the polysaccharides were dried in vacuo at $100^{\circ}$, over $\mathrm{P}_{2} \mathrm{O}_{5}$ for several hours.

Blue value (B.v.) was determined by the method of Bourne, Haworth, Macey \& Peat (1948).

Paper chromatography. Descending chromatograms were carried out at room temperature using Whatman no. 1 paper and a mixture of $10 \mathrm{ml}$. glacial acetic acid and $90 \mathrm{ml}$. of $75 \%(\mathrm{v} / \mathrm{v})$ aqueous isopropanol as solvent (Bird \& Hopkins, 1954). Development was by spraying with aniline oxalate (Partridge, 1949), urea oxalate (McGilvray, 1949) and ammoniacal silver nitrate (Trevelyan, Procter \& Harrison, 1950). The rate of movement ( $R_{G}$ values) of sugars was determined by dividing the distance moved by the sugars from the starting line by the distance moved by D-glucose $\left(R_{\theta}=1\right)$ under identical conditions.

$\alpha$-Amylolysis. $\alpha$-Amylolysis was investigated by adding salivary amylase solution $(5 \mathrm{ml}$.) to the glycogen $(c a .40 \mathrm{mg}$.) dissolved in $0.2 \mathrm{M}$ phosphate buffer ( $\mathrm{pH} \mathrm{7.0;} 4 \mathrm{ml}$.), aqueous sodium chloride $(3 \%, \mathrm{w} / \mathrm{v} ; 1 \mathrm{ml}$.) and distilled water (40 ml.). Samples (2 or $3 \mathrm{ml}$.) were withdrawn at intervals for determination of reducing power, as maltose. The salivary amylase solution was prepared by dissolving freezedried saliva in distilled water, and removing insoluble material with the centrifuge; the solution contained traces of maltotriase but showed no maltase activity.

Sedimentation constant. The rates of sedimentation of the glycogens $(1 \%, \mathrm{w} / \mathrm{v}$, solution in $\mathrm{M}-\mathrm{NaCl})$ were determined using an electrically driven 'Spinco' ultracentrifuge (Specialized Instruments Corporation, Belmont, California), as described by Greenwood \& Manners (1955). We are indebted to Dr C. T. Greenwood for these determinations. 